\title{
Humidifier disinfectant disaster: what is known and what needs to be clarified
}

\author{
Sungkyoon Kim, Domyung Paek \\ Graduate School of Public Health, Seoul National University, Seoul, Korea
}

Objectives After the initial investigations by the Korea Centers for Disease Control in 2011, over 1000 suspicious cases of humidifier disinfectant (HD) victims were subsequently reported by 2015 , and numbers are still increasing dramatically in 2016 in the midst of the prosecutors' office investigation. This study attempts to summarize the current understandings of the related health effects of HD based upon a systemic review of published epidemiologic studies and toxicology investigations.

Methods Published studies of HDs were searched through PubMed and TOXLINE under the search words 'humidifier disinfectant,' and related reports were identified from the references and published report list of regulatory agencies including the Korean $\mathrm{Na}$ tional Institute of Environmental Research, US Environmental Protection Agency, and EU European Chemicals Agency.

Results Case reports and epidemiologic studies have reported the clinical features of severe forms of HD lung damage, together with epidemiologic findings of seasonal occurrence and demographic variations, including the heightened susceptibility of young children. Toxicological studies have reported inhalation toxicities together with positive findings of in vitro genotoxicity studies.

Conclusions This study examined unsolved issues based on cases of upper respiratory diseases and diseases of other organs, including cancers, among suspected victims of HDs. These issues should be clarified in future research for the management and prevention of health effects from HDs and chemicals of other related household products.

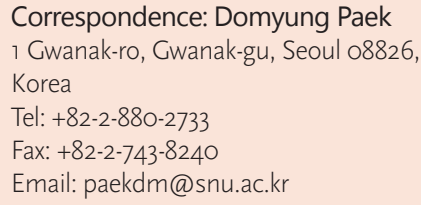

Received: July 11, 2016

Accepted: December 4, 2016

Published: December 4, 2016

This article is available from: http://e-eht.org/

\section{Keywords Humidifier disinfectant, Reviews, Epidemiology, Toxicology, Magnitude of victims}

\section{Introduction}

The humidifier disinfectant (HD) disaster began in April 2011 when the Korea Centers for Disease Control and Prevention (KCDC) received reports on six perinatal patients hospitalized in intensive care units. Since then, efforts have been made to find the truth regarding the health damage caused by toxic HDs and recovery efforts are still underway. Even before the prosecutor's criminal investigation began in 2016, the details regarding the causal relationships between health damage and the exposure to HDs have been among Korea's hotly debated issues. As social interest increased due to the criminal investigation, the issues concerning the range of health damage resulting from exposure have newly emerged. Above all, the number of people has increased to thousands at the start of the investigation and continues to rise.

Therefore, the purpose of this paper is to highlight issues which should be further clarified regarding health damage caused by toxic HDs from the perspectives of epidemiology and toxicology, in addition to summarizing the hitherto known facts. By reviewing the literature, this paper specifically tries to clarify the causal relationships (between health damage and HD) and to suggest the management systems that are needed in more detail. 


\section{Materials and Methods}

PubMed and TOXLINE databases were used for the literature review on health damage caused by toxic HDs. For PubMed, 'humidifier disinfectant' was the key search phrase and for TOXLINE, 'polyhexamethylene guanidine phosphate (PHMG),' 'oligo(2-(2-ethoxy) ethoxyethyl guanidinium (PGH),' 'polyhexamethylene biguanide hydrochloride (PHMB),' 'chloromethylisoehiasolinone (CMIT),' 'methylisothiazolinone (MIT),' and other chemical names were used as the key search words.

Considering the fact that there are a lot of unpublished reports on toxicity, the reference lists of these unpublished reports and the reports from institutions studying toxic experimentation were used as sources on/for toxicity.

PubMed was used to search epidemiological and clinical reports published before June 2016. After excluding unrelated or overlapping papers, 10 articles out of 41 publications remained. In the case of content concerning the magnitude and the status of exposure to toxic HDs, two articles and two unpublished reports were found in the reference lists of other research papers. For toxicity studies, in addition to 'PubMed' and 'TOXLINE', the latest reports and published lists from the Korean National Institution of Environmental Research, US Environmental Protection Agency, and European Chemicals Agency were reviewed.

In this paper, the excerpts of the main results of these articles and reports were summarized. In cases of epidemiological investigations, the study results were organized according to research design; in cases of toxicology tests, similar chemicals were grouped together according to the toxicological assessment for easy comparison.

\section{Results}

\section{Association Between the Usage of Humidifier Disinfectants and Pulmonary Diseases Epidemiological Studies}

The results of a case-control study of adult patients, which was conducted by the lead of KCDC in 2011, was finally published in a journal in 2014. The study of pediatric patients started after the study on adult patients, but was published in a journal in 2013 (Table 1).

Thus far, epidemiological studies that examine the causal association between HDs and health effects can be classified into two types: (1) case-control studies that examine the association between HD exposure and severe lung injuries; (2) retrospective cohort studies that examine all the family members of the victims to find out whether or not they were exposed to HDs and whether there were any subsequent incidences of diseases developing.

Each type of study shows a strong association between the use of $\mathrm{HD}$ and severe lung injuries even when indoor fungus or other chemical usage were taken into consideration.

The case-control studies were different in their subjects and controls: (1) children with hospital control, (2) adults with hospi-

Table 1. Case-control studies on the association between HD use and lung injury, as of May 2016

\begin{tabular}{|c|c|c|c|}
\hline Authors (publication year) & Cases (n) & Controls & Findings \\
\hline Yang et al. (2013) [1] & $\begin{array}{l}16 \text { (median age: } 26 \text { mo) from } \\
2010 \text { and } 2011\end{array}$ & $\begin{array}{l}\text { Hospital based 1:3 match by age and sex, and } \\
\text { index date of } 3 \text { groups of acute lobar } \\
\text { pneumonia, asthma, and healthy children }\end{array}$ & $\begin{array}{l}\text { OR, } 2.73 ; 95 \% \mathrm{Cl}, 1.41,5.90 ; \\
p<0.01 \text { (23\% usage rate among controls) }\end{array}$ \\
\hline Kim et al. (2014) [2] & 18 & 121 hospital-based matched by age and sex & $\begin{array}{l}\text { Humidifier OR, } 4.4 \\
\text { HD OR, } 47.3 \text { ( } 26 \% \text { usage rate among controls) } \\
\text { Insecticide use OR, } 3.9\end{array}$ \\
\hline Park et al. (2016) [3] & 16 & $\begin{array}{l}60 \text { community-based controls 1:4 match by } \\
\text { age, sex, residence, history of child birth }\end{array}$ & $\begin{array}{l}\text { HD OR, } 116.1 \text { ( } 22 \% \text { usage rate among controls) } \\
\text { Positive association with years of cumulative } \\
\text { exposure, months of exposure duration, } \\
\text { amount of exposure per day }\end{array}$ \\
\hline
\end{tabular}

$\mathrm{HD}$, humidifier disinfectant; OR, odds ratio; $\mathrm{Cl}$, confidence interval.

Table 2. Retrospective cohort study on the association between HD use and lung injury using the first round of victim registration records, as of May 2016

\begin{tabular}{|c|c|c|c|}
\hline $\begin{array}{l}\text { Authors } \\
\text { (publication year) }\end{array}$ & Cohort & Outcomes & Findings \\
\hline Paek et al. (2015) [4 & $\begin{array}{l}\text { In total, } 1002 \text { subjects from } 273 \text { familie } \\
\text { with } 734 \text { exposed, } 546 \text { of them to } \\
\text { PHMG, and the other } 268 \text { unexposed }\end{array}$ & $\begin{array}{l}117 \text { definite and } 34 \text { probable cases of HD } \\
\text { lung injury based upon combinations of } \\
\text { pathologic, radiographic, and clinical } \\
\text { criteria }\end{array}$ & $\begin{array}{l}\text { The finding that a certain minimum period of intense } \\
\text { exposure is apparently necessary for the development of } \\
\text { HD lung injury may explain the reversible process of } \\
\text { incidental family cases found to have the same radiographic } \\
\text { findings as in the full-blown cases with less severe or no } \\
\text { symptoms }\end{array}$ \\
\hline
\end{tabular}

HD, humidifier disinfectant; PHMG, polyhexamethylene guanidine phosphate. 
tal control, (3) and adults with community control. However, the exposure rates to HDs in controls were 23,26 , and $22 \%$ in each study, respectively. Accordingly, the results show that exposure rate to $\mathrm{HD}$ in the general population was over $20 \%$ (Table 1 ).

The assessment committee classified severe lung injuries into four levels in the association with HD exposure: level 1 (definite), level 2 (probable), level 3 (possible), and level 4 (unlikely). In 2013, 151 victims were categorized into level 1 and level 2 upon first round assessment. At that time, daily amount of $\mathrm{HD}$ and time used were associated with severe lung injuries (Table 2).

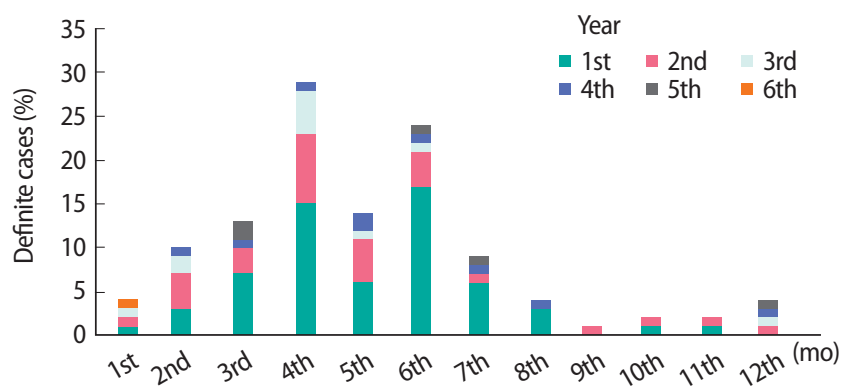

Figure 1. Months of exposure before symptom development for definite cases. Adapted from Paik et al. Ann Am Thorac Soc 2015;12(12):1813$1821[4]$.
In addition, the number of cases (symptom development) increased as the time of exposure increased. When looking at the data in a monthly pattern, the symptoms of confirmed cases increased with the increase of months of exposure, peaked after four to six months, and then decreased, but they increased again after 12 months, showing a peak over the next four months (Figure 1). In other words, since the use of humidifiers was seasonal, the symptom breakout of confirmed cases showed a similar seasonal pattern as well.

As was revealed by case reports, the clinical conditions of toxic HDs are more affected by the environment of families than by genetic causes, because about $20 \%$ of cases reported victims within a family and less than $10 \%$ of cases had underlying lung disease (Table 3).

Radiological findings in the early period of hospitalization provided important information for patients' prognosis with lung injuries by HDs, and clinical laboratory tests on inflammation have also been helpful to predict prognosis.

\section{Animal Studies}

Several animal studies to examine the toxicity of HDs have been reported, where the HDs were divided into two classes: (1) gua-

Table 3. Case report studies on HD use and lung injury, as of May 2016

\begin{tabular}{|c|c|c|}
\hline $\begin{array}{l}\text { Authors, } \\
\text { (publication year) }\end{array}$ & Cases & Findings \\
\hline Lee et al. (2013) [5] & 16 (from 2006 to 2011) & $\begin{array}{l}26 \text { mo old } \\
44 \% \text { mortality } \\
\text { Children's lung disease with bronchiolitis obliterans pattern }\end{array}$ \\
\hline Kim et al. (2014) [6] & $\begin{array}{l}\text { Nationwide ascertainment of } 138 \text { cases of children's } \\
\text { interstitial lung disease from } 2006 \text { to } 2011\end{array}$ & $\begin{array}{l}30.4 \text { mo old } \\
\text { M:F } 1.3: 1 \\
21 \text { d of cough before admission } \\
10 \% \text { underlying disease } \\
19 \% \text { familial cases } \\
\text { No more cases observed for } 2 \text { yr after HD ban }\end{array}$ \\
\hline Hong et al. (2014) [7] & & Familial cluster 24\%, $30 \mathrm{~d}$ before admission \\
\hline Yoon et al. (2015) [8] & 47 (HD associated children's interstitial lung disease) & $\begin{array}{l}\text { CT features were characterized by chronological changes, from consolidation to } \\
\text { centrilobular opacities, and lesions eventually became faint centrilobular nodules } \\
\text { Histopathologic features were bronchocentric-distributed fibro-inflammatory lesions, } \\
\text { which were more profound in the advanced stage than the early stage }\end{array}$ \\
\hline Kim et al. (2016) [9] & 17 (children) & $\begin{array}{l}\text { Seven of the } 17 \text { children were survivors } \\
\text { Compared to survivors, non-survivors had greater ground-glass attenuation on follow- } \\
\text { up chest tomography, higher admission neutrophil counts, and more macrophages on } \\
\text { pathologic findings } \\
\text { Transforming growth factor-beta } 1 \text { persisted at an elevated level (1000-1500 pg/mL) in } \\
\text { survivors, whereas it decreased abruptly in non-survivors }\end{array}$ \\
\hline Koo et al. (2016) [10] & 59 (adults) & $\begin{array}{l}\text { Almost half needed ICU admission ( } 47.5 \% \text { ) and } 17 \text { died ( } 28.8 \%) \\
\text { Young age, peripartum and low oxygen saturation were factors associated with ICU } \\
\text { admission } \\
\text { On initial chest radiographs, consolidation ( } p<0.001) \text { and ground-glass opacity }(p=0.01) \\
\text { were significantly noted in patients who required ICU admission } \\
\text { CT findings including consolidation }(\mathrm{OR}, 1.02) \text {, pneumomediastinum }(\mathrm{OR}, 1.66) \text { and } \\
\text { pulmonary interstitial emphysema }(\mathrm{OR}, 1.61) \text { were the risk factors for lung } \\
\text { transplantation and mortality }\end{array}$ \\
\hline
\end{tabular}

HD, humidifier disinfectant; $M$, male; F, female; OR, odds ratio; CT, computed tomography; ICU, intensive care units. 
Table 4. Animal toxicity studies on major chemicals used for humidifier disinfectants

\begin{tabular}{|c|c|c|c|c|}
\hline & PHMG & PGH & PHMB & MIT/CMIT \\
\hline $\begin{array}{l}\text { Acute oral } \\
\text { exposure }\end{array}$ & $\begin{array}{l}\text { PHMG LD50 } 600 \mathrm{mg} / \mathrm{kg} \\
\text { Convulsion PHMG LD } 50 \\
\text { Mice } 450 \mathrm{mg} / \mathrm{kg}, 600 \mathrm{mg} / \mathrm{kg} \\
\text { Rats } 630 \mathrm{mg} / \mathrm{kg}, 830 \mathrm{mg} / \mathrm{kg}, 760 \mathrm{mg} / \mathrm{kg} \\
\text { Guinea pigs } 750 \mathrm{mg} / \mathrm{kg}, 840 \mathrm{mg} / \mathrm{kg} \text {, } \\
900 \mathrm{mg} / \mathrm{kg} \\
\text { Similar lethal dose for different } \\
\text { molecular size, toxicity depends on } \\
\text { total mass [11-13] }\end{array}$ & $\begin{array}{l}\text { Akacid plus }{ }^{\circledR} \\
\text { (PGH: 1:3 PHMG=3:1 mixture) } \\
\text { Rats LD } D_{50} 2000 \mathrm{mg} / \mathrm{kg}[14]\end{array}$ & $\begin{array}{l}\text { Female SD rats } 2 \text { wk gavage LD50 } \\
1049 \text { mg/kg (lung, liver, kidney, } \\
\text { stomach lesions on autopsy) } \\
2000 \text { mg/kg LD } D_{50} \text { (neurotoxicity); } \\
\text { Alderley Park rats } 2 \text { wk gavage LD } \\
500 \text { mg/kg [15] }\end{array}$ & $\begin{array}{l}\text { CMIT/MIT LD } 4042 \mathrm{mg} / \mathrm{kg} \text { bw } \\
465 \mathrm{mg} / \mathrm{kg} \text { bw for male, } 393 \mathrm{mg} / \mathrm{kg} \\
\text { bw for female }[11,16]\end{array}$ \\
\hline $\begin{array}{l}\text { Chronic oral } \\
\text { exposure }\end{array}$ & $\begin{array}{l}\text { No difference in toxicity by molecular } \\
\text { size } \\
\text { Subacute oral toxicity - liver, } \\
\text { neurotoxicity, immune-toxicity by } \\
\text { affecting thymus, fibrosis [11] }\end{array}$ & $\begin{array}{l}\text { Piloerection, decrease in activity, } \\
\text { lethargy, teeth discoloration, weight } \\
\text { loss, male prostate, thymus, lung } \\
\text { weight decrease, female thymus } \\
\text { weight decrease, lung weight } \\
\text { increase abnormal lung pathology } \\
\text { [11] }\end{array}$ & $\begin{array}{l}\text { Repeated subacute oral exposure-for } \\
\text { high dose group, cholesterol level } \\
\text { and liver function test abnormal } \\
\text { LOAEL } 0.1 \mathrm{mg} / \mathrm{mL} \\
\text { Chronic toxicity NOAEL } 1 \text { yr } 54 \mathrm{mg} / \\
\text { kg, } 2 \text { yr } 36-45 \mathrm{mg} / \mathrm{kg} \text { [18] }\end{array}$ & $\begin{array}{l}\text { CMIT/MIT 14\%, 101, 363, } 555 \mathrm{mg} \\
\text { (a.i.)/kg beagle dog, } 90 \mathrm{~d} \\
\text { No deaths, weight loss for high dose } \\
\text { group, no change in organ weight } \\
\text { NOAEL } 555 \mathrm{mg} \text { (a.i.)/kg [17] }\end{array}$ \\
\hline $\begin{array}{l}\text { Acute inhalation } \\
\text { exposure }\end{array}$ & & & $\begin{array}{l}\text { PHMB 0.1, 0.3, } 0.5 \mathrm{mg} / \mathrm{L}, 4 \mathrm{hr} \\
\text { MMAD } 1.49-2.20 \mu \mathrm{m} \\
\text { Lung and airway discoloration on } \\
\text { autopsy } \\
\text { LD } 0.29 \mathrm{mg} / \mathrm{L} \text { for male, } 0.48 \mathrm{mg} / \mathrm{L} \\
\text { for female }[18]\end{array}$ & $\begin{array}{l}\text { CMIT/MIT LD } D_{50} 2.36 \mathrm{mg} / \mathrm{L} \text { rat MIT } \\
97.8 \%, 0.046,0.012,0.15,1.07 \text {, } \\
2.09 \mathrm{mg} / \mathrm{L}, 4 \mathrm{hr} \text { rat } \\
\text { Congestion in all lobes of lung, } \\
\text { stomach lesion } \\
\text { LC } \mathrm{C}_{50} 0.11 \mathrm{mg} / \mathrm{L} \text { rat MIT } 53.52 \%, 0.15 \text {, } \\
0.25,0.47,0.68 \mathrm{mg} / \mathrm{L}, 4 \mathrm{hr} \text { rat } \\
\text { Autopsy lung congestion, intestine } \\
\text { dilatation } \mathrm{LC} \mathrm{C}_{50} 0.35 \mathrm{mg} / \mathrm{L},[11,19]\end{array}$ \\
\hline $\begin{array}{l}\text { Subacute } \\
\text { inhalation } \\
\text { exposure }\end{array}$ & $\begin{array}{l}\text { PHMG } 1.6 \mathrm{mg} / \mathrm{m}^{3} 6 \mathrm{hr}, 5 \mathrm{~d}, 4 \mathrm{wk} \\
\text { CT image: similar to human case } \\
\text { Pathology: inflammation, fibrosis } \\
\text { SD rats } 1.6 \mathrm{mg} / \mathrm{m}^{3} 6 \mathrm{hr} / \mathrm{d}, 5 \mathrm{~d} / \mathrm{wk}, 4 \\
\text { wk, inflammation and fibrotic change } \\
\text { after lung injury [12] }\end{array}$ & $\begin{array}{l}\text { SD rats } 4 \text { wk } \\
\text { Smaller mass median diameter for high } \\
\text { dose-recovery group male prolonged } \\
\text { prothrombin time lung pathology- } \\
\text { inflammation, fibrosis Nose- } \\
\text { degenerative changes and recovery with } \\
\text { transitional epithelium Trachea-epithelial } \\
\text { change pharynx-squamous cell } \\
\text { metaplasia alveolar lavage-neutrophil } \\
\text { and lymphocyte, LDH increase, target } \\
\text { organ: lung, pharynx, spleen, trachea } \\
\text { NOAEL male } 0.10 \mathrm{mg} / \mathrm{m}^{3} \text {, female } 0.50 \\
\mathrm{mg} / \mathrm{m}^{3}[11]\end{array}$ & $\begin{array}{l}4 \text { wk subacute toxicity - NOAEL } 0.024 \\
\mathrm{mg} / \mathrm{m}^{3} \text { - pharynx, lung, thymus [18] }\end{array}$ & $\begin{array}{l}\text { CMIT/MIT } 14 \% 0.34,1.15,2.64 \mathrm{mg} / \\
\mathrm{m}^{3}, 6 \mathrm{hr}, 5 \mathrm{~d}, 13 \text { wk } \\
\text { No deaths, weight loss for high dose } \\
\text { group } \\
\text { Breathing difficulty blood protein } \\
\text { decrease for high dose group spleen } \\
\text { weight loss for high dose group nose } \\
\text { and other respiratory tract pathologic } \\
\text { abnormality } \\
\text { NOAEL } 0.34 \mathrm{mg} / \mathrm{m}^{3}[17]\end{array}$ \\
\hline $\begin{array}{l}\text { Reproductive } \\
\text { toxicity }\end{array}$ & $\begin{array}{l}\text { SD rats } 120 \mathrm{mg} / \mathrm{kg} \text { oral exposure, } \\
\text { wheezing, uterine prolapse, low birth } \\
\text { weight } \\
\text { NOAEL male } 13 \mathrm{mg} / \mathrm{kg} / \mathrm{d} \text {, female and } \\
\text { next generation } 40 \mathrm{mg} / \mathrm{kg} / \mathrm{d} \text { [11] }\end{array}$ & $\begin{array}{l}\text { Weight loss, weight increase for } \\
\text { prostate, thymus, and lung } \\
\text { Reproductive organ-no toxicity but } \\
\text { lung pathology exam abnormal } \\
\text { PHMG NOAEL male female both } 80 \\
\text { mg/kg/d [11] }\end{array}$ & $\begin{array}{l}\text { Reproductive toxicity-negative } \\
\text { Developmental toxicity-negative-but } \\
\text { through effect on mother } \\
\text { Rats } 112 \mathrm{mg} / \mathrm{kg} \text { oral exposure } \\
\text { fetotoxicity from maternal toxicity } \\
\text { [15] }\end{array}$ & \\
\hline $\begin{array}{l}\text { In vitro } \\
\text { genotoxicity }\end{array}$ & & & In vitro genotoxicity - negative [18] & $\begin{array}{l}\text { CMIT/MIT 28, } 30 \mathrm{mg} / \mathrm{kg} 1 / \mathrm{d}, 5 \mathrm{~d} \text {, negative } \\
\text { [18] }\end{array}$ \\
\hline $\begin{array}{l}\text { In vivo } \\
\text { micronucleus } \\
\text { test }\end{array}$ & $\begin{array}{l}\text { PHMG: } 125,250,500 \mathrm{mg} / \mathrm{kg} 1 / \mathrm{d} \text { for } \\
2 \mathrm{~d} \\
\text { Decrease in activity, no weight change } \\
\text { [11] }\end{array}$ & $\begin{array}{l}\text { PGH: 500, 1000, } 2000 \mathrm{mg} / \mathrm{kg} 1 / \mathrm{d} \text { for } \\
2 \mathrm{~d} \\
\text { Decrease in activity, no weight } \\
\text { change, no cytotoxicity in bone } \\
\text { marrow, no genotoxicity [11] }\end{array}$ & $\begin{array}{l}\text { In vivo genotoxicity - negative } \\
\text { PHMB 250, } 400 \text { mg/kg after 24, 48, } \\
72 \text { hr negative micronucleus test } \\
\text { PHMB 147, } 294 \text { mg/kg after 4, } 12 \text { hr, } \\
\text { negative DNA synthesis [18] }\end{array}$ & $\begin{array}{l}\text { CMIT/MIT 50, 500, } 60 \mathrm{mg} / \mathrm{kg} \text {, negative } \\
\text { [18] }\end{array}$ \\
\hline Carcinogenicity & & & $\begin{array}{l}\text { Carcinogenicity -hemangiosarcoma } \\
\text { positive at } 2000 \text { ppm [18] }\end{array}$ & \\
\hline $\begin{array}{l}\text { Skin irritation, } \\
\text { sensitization }\end{array}$ & $\begin{array}{l}\text { Human skin in vitro } \mathrm{LD}_{50}, 1.7 \mathrm{ppm} \\
\text { apoptosis, cell survival and aging } \\
\text { effect from long term exposure [11] }\end{array}$ & $\begin{array}{l}\text { Human skin in vitro } L_{50} 3 \text { ppm } \\
\text { apoptosis, cell survival and aging } \\
\text { effect from long term exposure } \\
\text { Akacid plus }{ }^{\circledR} \text { rats dermal LD } D_{50} 2000 \\
\text { mg/kg [14] }\end{array}$ & $\begin{array}{l}\text { Ocular irritation positive, skin } \\
\text { sensitization } \\
\text { Human patch test-positive in } 0.5-16 \% \\
\text { [18] }\end{array}$ & $\begin{array}{l}\text { Rabbit effective dose } 1.5 \% \text { skin } \\
\text { irritation [17] }\end{array}$ \\
\hline
\end{tabular}

PHMG, polyhexamethylene guanidine phosphate; PGH. oligo(2-(2-ethoxy) ethoxyethylguanidinium; PHMB, polyhexamethylene biguanide hydrochloride; MIT/CMIT, methylisothiazolinone/chloromethylisothiazolinone; LDH, lactate dehydrogenase; LD 50 , lethal dose 50; LOAEL, lowest observed adverse effect level; NOAEL, no observed adverse effect level; CT, computerized tomography; LC 50 , lethal concentration 50; MMAD, mass median aerodynamic diameter. 
nine polymer substances such as PHMG, PGH; (2) PHMB, and isothiazolinone substances such as CMIT and MIT (Table 4).

Both guanine and isothiazolinone substances showed comparable toxicities in similar concentration at acute oral and inhalation toxicity.

Chronic toxicity was found in the liver where substances absorbed through the gastrointestinal tract pass first under repeated oral exposure and in high dosage, resulting in neurotoxicity and immune-toxicity by affecting the thymus. The report that lung damage was also found in spite of oral exposure suggests the possibility that the damage could have occurred by mechanisms other than air exposure.

Under repeated inhalation exposure as in chronic toxicity tests, damage in the larynx and nasal cavities was observed in high levels for both guanine polymers and isothiazolinone substances. With guanine specifically, respiratory lesions lasted for a substantial period of time after exposure stops and in the recovery stage; therefore, the damage in respiratory organs by inhalation exposure, thereby, could be similar to humans.

The result for genotoxicity was positive before the metabolism of guanine polymer substances, while it was negative after metabolism. Therefore, in cases where absorption exposure occurs without passing through the liver such as in respiratory inhalation, the mechanism of the toxic effect should be examined. For PHMB in particular, genotoxicity and carcinogenicity of directly exposed organs through direct inhalation or oral exposure should be investigated since angiosarcoma develops in the liver by oral exposure.

Even though the results differ slightly, skin irritation and hypersensitivity was reported, specifically irritation and hypersensitivity to the mucous membranes, so research on the mechanism should be examined.

\section{Further Investigation Needed Regarding Causal Relationships}

Between Humidifier Disinfectants and Lung Injury

Although studies have revealed the toxicity of HDs and how they cause severe lung injury, more detailed studies are needed. In particular, the following aspects related to lung injury caused by HDs are receiving attention.

\section{Exposure conditions and characteristics of the susceptible population}

Current research reports that the exposure characteristics to HDs is one of the factors that cause lung injury. Age, along with exposure conditions, also significantly increase the risk of lung injury (Figure 2). Reports show a higher prevalence of lung injury in children; therefore, there is a need for a systematic investigation of factors that cause varying levels of susceptibility by age as well as pathological information on lung injury. In this respect,

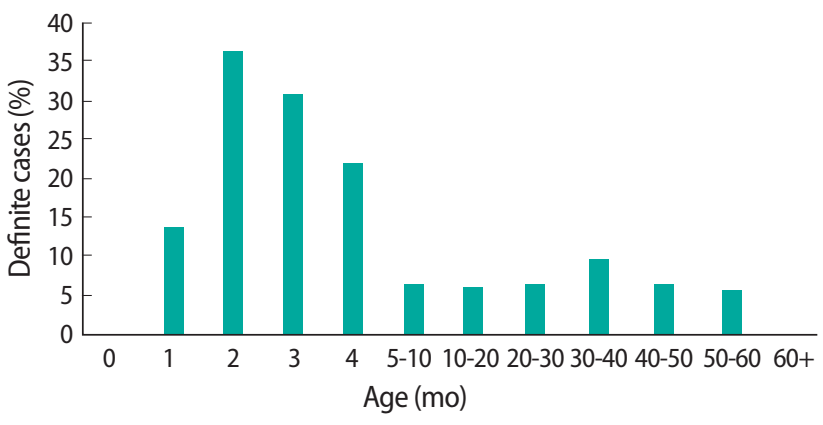

Figure 2. Proportion of definite cases by age group. Adapted from Paik et al. Ann Am Thorac Soc 2015;12(12):1813-1821 [4]

further research is needed to examine how reversible the lung injury is based on the degree of exposure for a certain period of time and the intensity of continued and concentrated exposure. Furthermore, future studies are needed to examine the susceptibility factors that determine the threshold for irreversibility.

\section{Mechanism of injury in patients with non-conventional exposure}

Studies found lung injury in animals that experienced concentrated exposure to HDs through oral administration. This result raises questions about chemicals causing respiratory damage, possibly through pathways other than the respiratory organs, such as the blood stream. As such, more research is needed on the pathogenesis of fetal injuries since chemical exposure is placental. Moreover, toxicity in the reproductive system caused by inhaled chemical exposure warrants thorough investigation.

\section{Natural course and prognostic factors of severe lung injury}

More research is also needed on the recovery time and/or the prognosis of lung disease as well as factors that affect prognosis. In this regard, along with the issues addressed earlier, the impact underlying diseases may have on the causes and progression of lung disease must be examined.

\section{Social and mental problems of the victims}

In addition to investigating lung disease, social and mental issues that current victims are facing need to be addressed, specifically how to manage and treat the victims' physical health conditions that impact their mental and social conditions.

\section{Identification of the Magnitude and Characteristics of Humidifier Disinfectant- related Diseases}

\section{Conditions of Usage and Exposure to Humidifier Disinfectants}

There are no studies that estimate the magnitude of all diseases caused by HDs. Existing research only estimates the usage of HDs and presumes the number of victims through their self-reports on symptoms. 
Table 5. Studies of HD use: exposure prevalence

\begin{tabular}{|c|c|c|c|}
\hline Authors (publication year) & Subjects & Usage rate & Other findings \\
\hline Jeon et al. (2012) [20] & Gyeonggi province 94 subjects & $\begin{array}{l}37 \% \text { ( } 35 \text { out of } 94 \text { ) used humidifier and } \\
18 \% \text { used HD }\end{array}$ & The younger, the higher the usage rate \\
\hline Chang et al. (2012) [21] & 1144 pregnant women & $\begin{array}{l}28 \% \text { usage rate of humidifier, during winter } \\
\text { season } 45 \% \text { usage rate }\end{array}$ & $\begin{array}{l}4.6 \mathrm{~d} / \mathrm{wk}, 7.3 \mathrm{hr} / \mathrm{d} \text { higher for multipara group } \\
\text { than primipara group }\end{array}$ \\
\hline ACCEH (2016) [22] & $\begin{array}{l}1000 \text { adults over } 19 \mathrm{yr}, \mathrm{ARS} \\
\text { (RDD) telephone survey } \\
\text { Response rate } 8.9 \%\end{array}$ & $22 \%$ usage rate of $\mathrm{HD}$ & $\begin{array}{l}\text { Out of those who had used HD, 20.9\% reported } \\
\text { respiratory problems }\end{array}$ \\
\hline
\end{tabular}

$H D$, humidifier disinfectant; ARS (RDD), automatic response service (random digit dialing).

Table 6. Studies of exposure characteristics of HD

\begin{tabular}{|c|c|c|c|}
\hline Authors (publication year) & Subjects & Findings & Other findings \\
\hline Lee et al. (2012) [23] & Simulation exposure & $\begin{array}{l}\text { The calculated exposure concentrations of HDs were } \\
0.10,0.016,0.42 \mathrm{ug} / \mathrm{L} \text { for PHMG, CMIT/MIT, and } \\
\text { PGH, respectively }\end{array}$ & $\begin{array}{l}\text { The risk quotients were } 2.5 \times 10^{3}, 9.4 \text {, and } 1.05 \\
\times 10^{4} \text { for PHMG, CMIT/MIT, and PGH, } \\
\text { respectively }\end{array}$ \\
\hline Park et al. (2014) [24] & 17 families & $\begin{array}{l}26 \text { patients (68\%) used the brand "Oxy" }{ }^{\circledR} \text {, which } \\
\text { contains PHMG } \\
\text { Of the ten patients with fatal lung injury, nine were } \\
\text { found to have used PHMG }\end{array}$ & $\begin{array}{l}\text { The patients used HD brands containing either } \\
\text { PHMG }(n=36) \text { or PGH }(n=2)\end{array}$ \\
\hline Park et al. (2014) [25] & $\begin{array}{l}374 \text { subjects with lung disease } \\
\text { patients and } 303 \text { of their family } \\
\text { members }\end{array}$ & $\begin{array}{l}\text { The distribution patterns of the intensity, duration, and } \\
\text { cumulative exposure to HDs for the patient group } \\
\text { were higher than those of the family group, especially } \\
\text { for pregnant women and patients } \leq 6 \text { yr old }\end{array}$ & \\
\hline
\end{tabular}

HD, humidifier disinfectants; PHMG, polyhexamethylene guanidine phosphate; PGH. oligo(2-(2-ethoxy) ethoxyethylguanidinium; MIT/CMIT, methylisothiazolinone/ chloromethylisothiazolinone.

Some data sets suggest that 18 to $22 \%$ of the general population has used and been exposed to HDs. This rate is almost equal to the control group's usage and exposure rate in the aforementioned case-control studies (Table 5).

Some studies have estimated the concentration of indoor exposure to HDs; when using the estimated exposure concentration to calculate the risk quotients for the active components in the disinfectants, the studies reported the concentration to be highly dangerous (Table 6). Furthermore, types and usage patterns of HDs were reported based on the registered cases having health effects due to HD exposure.

\section{Scope and Magnitude of Humidifier Disinfectant-related Diseases} Range of related diseases derived from epidemiological studies

Upon reviewing the diagnosed diseases of the victims who reported health concerns in the first round of the HD injury survey, the victims were found to have diseases other than those that are lung-related (including acute interstitial pneumonitis) such as cancer, ear, nose and throat diseases, and skin conditions. This suggests that HD-related diseases could be more extensive (Table 7).

In particular, of the reported victims, those in level 3 ('possible') and level 4 ('unlikely') showed diseases directly related to respiratory exposure such as chronic bronchitis, sinusitis, and rhinitis. Other reported diseases such as tuberculosis and immunity-related cancer could be also associated with respiratory exposure.

\section{Range of related diseases derived from animal studies}

Currently, animal studies report that HDs affect not only lung tissue but also various other organs.

First of all, acute toxicity effects from oral exposure are reported to cause the following: direct damage on the gastrointestinal mucosa, hepatotoxicity accompanied by prolonged prothrombin coagulation time and changes in cholesterol level, neurotoxicity with seizures, and immunotoxicity along with changes in the thymus and immunocytes. Damage to lung tissue from oral exposure has also been reported. These reports collectively suggest the possibility of oral absorption affecting lung tissue. However, in order to understand the scope of HD-related diseases that significantly affect humans, research is needed to examine what kinds of secondary damage occurs after primary damage is done to the main target organs when exposed to concentrated toxins. Furthermore, studies must also identify what initial damage occurs in cases of low concentration exposure.

Furthermore, acute toxicity through inhalation has been reported to cause damage to the upper respiratory and whole respiratory tract including the lungs, bronchus, larynx, and nasal cavity. The direct damage caused by concentrated inhalation needs to be distinguished from those which are recoverable and those which are irreversible.

On the other hand, both guanine polymers and isothiazolinone have been reported to cause skin and mucous irritation and allergic sensitization when exposed in low concentration for an ex- 
Table 7. Underlying diseases and original diagnosis of suspected victims in the first round of humidifier disinfectant injury survey

\begin{tabular}{|c|c|c|c|c|c|c|c|c|}
\hline & $\begin{array}{l}\text { Level } 1 \\
\text { (definite) }\end{array}$ & $\begin{array}{l}\text { Leve1 } 2 \\
\text { (probable) }\end{array}$ & $\begin{array}{c}\text { Level } 3 \\
\text { (possible) }\end{array}$ & $\begin{array}{c}\text { Level } 4 \\
\text { (unlikely) }\end{array}$ & Reassessment & $\begin{array}{c}\text { Exposed } \\
\text { no-checkup }\end{array}$ & Not exposed & Subtotal \\
\hline Subtotal & 117 & 34 & 38 & 140 & 45 & 360 & 268 & 1002 \\
\hline \multicolumn{9}{|l|}{ Underlying disease } \\
\hline Yes & $2(1.7)$ & $3(9.1)$ & $8(22.2)$ & $34(25.0)$ & $9(21.4)$ & & & \\
\hline No & $113(98.3)$ & $30(90.9)$ & $28(77.8)$ & $102(75.0)$ & 33 (78.6) & & & \\
\hline \multicolumn{9}{|l|}{ Original diagnosis } \\
\hline Acute interstitial pneumonia & 23 & 5 & 1 & 0 & 6 & & & 35 \\
\hline Pneumonia & 18 & 7 & 3 & 36 & 8 & & & 72 \\
\hline Interstitial lung disease & 60 & 6 & 10 & 18 & 14 & & & 108 \\
\hline Pneumonitis & 9 & 4 & 0 & 4 & 4 & & & 21 \\
\hline Acute airway disease & 1 & 1 & 1 & 21 & 3 & & & 27 \\
\hline Tuberculosis & 2 & 2 & 2 & 0 & 0 & & & 6 \\
\hline Chronic airway disease & 0 & 0 & 3 & 2 & 0 & & & 5 \\
\hline Other lung disease & 0 & 0 & 1 & 5 & 1 & & & 7 \\
\hline Cancer & 0 & 0 & 0 & 4 & 0 & & & 4 \\
\hline ENT problems & 0 & 0 & 1 & 7 & 1 & & & 9 \\
\hline Respiratory symptoms & 1 & 5 & 12 & 19 & 1 & & & 38 \\
\hline Other non-respiratory symptoms & 0 & 0 & 0 & 4 & 2 & & & 6 \\
\hline No symptoms & 3 & 4 & 4 & 20 & 5 & 360 & 268 & 664 \\
\hline
\end{tabular}

Adapted from Paik et al. Ann Am Thorac Soc 2015;12(12):1813-1821 [4].

Values are presented as number or number (\%).

ENT, ear, nose and throat.

tended period of time. Isothiazolinone, specifically, is widely found and all organs exposed to it are presumably directly affected based on certain levels of cell toxicity. Furthermore, some suggest that the substances may become absorbed in the systemic circulation when exposed chronically which could cause genetic toxicity, reproductive toxicity, and cancer. Therefore, further studies should investigate the health effects and damage HDs may have on all organs of the body based on the toxicants' rate of exposure, absorption, metabolism, damage, and recovery in different exposure conditions such as exposure concentration, frequency, and duration.

In conclusion, reports on toxicity suggest a wider range of affected organs throughout the body that goes beyond severe lung disease.

\section{Estimation of the magnitude of all diseases related with humidifier disinfectant exposure}

According to the previous studies, approximately 11 million people, or $22 \%$ of the general population (Table 5), have been exposed to substances in HDs. With reference to the survey results submitted to court regarding the degree of exposure, two out of 60 were exposed to highly concentrated amounts of toxicants. This means approximately three million people were exposed to levels higher than the 'no observed adverse effect' level on a toxicological screening. This figure may be used to estimate the magnitude of all diseases related with $\mathrm{HD}$ exposure.

\section{Future Research on Humidifier Disinfectant-related Diseases} Other Than Lung Injury

In order to identify the magnitude and range of all health effects caused by HDs exposure, research on the following issues are crucial.

Current animal experiments are conducted based on standardized methods, following a consistent schedule, frequency, and period of exposure. Unlike the controlled environment used in animal testing, humans can be exposed 24 hours a day, seven days a week, all year. Future animal study, therefore, needs to make adjustments to examine the effects of concentrated and continuous exposure without a period of recovery. Studies are needed to investigate in acute exposure how the effects will vary in accordance to the changes in the concentration level of exposure, duration, and frequency of exposure along with age difference. Furthermore, studies should examine various target organs in varying stages of exposure in order to measure the range of health effects caused by HD exposure. For more accurate measurements, future investigations should first research toxicokinetics for the main exposure pathways and discover how toxicants are absorbed and metabolized via each route (Table 8).

Meanwhile, the range of health effects that have been reported by $\mathrm{HD}$ victims is partly centered around mass media coverage data, which could create discrepancies in actual users. A more systematic investigation is needed, considering the general population as study subjects and the conditions of actual usage, exposure, and side effect occurrences to pursue whether the study 
Table 8. Variables of manipulation in animal toxicology study on major chemicals used for humidifier disinfectants

\begin{tabular}{llll}
\hline Variables & & Kinetics & Dynamics \\
\hline Chemicals & Single, multiple, interactions & {$[11-19]^{\mathrm{a}}$} \\
Exposure dose & Relevant to human exposure & {$[11-19]^{\mathrm{a}}$} \\
Exposure route & Oral, inhalation, skin & {$[11-19]^{\mathrm{a}}$} \\
Exposure pattern & Duration without recovery, recovery period, frequency & {$[11-19]^{\mathrm{a}}$} & \\
Susceptibility & Sex, age, species, strains, w/wo underlying disease & {$[11-19]^{\mathrm{a}}$} \\
End points & Gross appearance, pathologic, biochemical, functional & {$[11-19]^{\mathrm{a}}$} \\
\hline
\end{tabular}

aBased on the review of the previous studies.

subjects received medical treatment and reported their conditions. With this new data set on health effects, researchers can cross-check data from previous studies and try to estimate the magnitude of each health effect by comparison of the types and degrees of health effects between data and by using the capturerecapture method.

In addition, follow-up studies on factors that affect susceptibility can provide insight into understanding all diseases' natural courses, especially for diseases that have long latent periods, such as cancer, or diseases that may cause secondary health damage.

Lastly, comprehensive socio-psychological studies, such as family relations, social activity, damage compensation, types of support and its relevance, and mental and behavioral effects and their changes in relation with HDs exposure are needed to understand the size and scope of health effects caused by HDs. Since most victims have been unexpectedly injured at a very young age, the whole scope of the health effects including psychological trauma and its changes over time must be evaluated.

\section{Discussion}

South Korea (hereafter Korea) is not yet fully equipped with the infrastructure-such as an overseeing agency or related legal regulations-for identifying and mediating issues regarding the injuries caused by HDs. As the current issues are being resolved, the HD case in Korea could change or new and specific plans may emerge to settle and manage the issues. In this current state, the following two points that reflect on past environmental pollution issues or track other countries' history of environmental pollution control can help Korea to investigate the current issue and provide future guidelines.

The first point to consider is that the causal relation between severe lung injury and exposure to HDs is specific. The 'specificity,' a specific disease related with a specific cause, is very rare in common cause and effect relationships. Mostly, a causal relationship shows non-specific relation, i.e., various causes of a disease or various diseases for a cause. In the case of HDs and their health effects, a combination of various causes may make up a spectrum of effects from specific to non-specific. The specific causal relationship is an exceptional phenomenon such as mesothelioma caused by exposure to asbestos. For example, lung cancer is considered the more significant effect of exposure to asbestos than mesothelioma, in which the causal relationship is confirmed, but when the effect of smoking is taken into consideration, lung cancer is a non-specific effect of asbestos exposure. When examining toxicants and their effects on lung and respiratory lesions, the most common complication from isethionate exposure or coal dust exposure is bronchitis, not alveolar lesions - exposure to isethionate is known to cause pulmonary fibrosis and exposure to coal dust, pneumoconiosis. As can be seen, a toxicant's physical characteristics can determine which area will be affected, the alveoli or respiratory tract, but in practice the effects of the exposure route and of all organs that participate in the metabolic process need to be considered within the scope of health effects due to the toxicants.

The second point to consider is the need to learn from other countries' experience. Japan's Minamata disease, for instance, was first discovered in the 1950s, and the range of injured victims is still under debate. This example delineates the importance of a timely evaluation of damage while also being aware of the possibility that the understanding of causal relationships could change over time. In other words, institutional, administrative, and social infrastructure could be established that could prevent, detect, and manage similar future damage if we can identify and manage Korea's HD damage and learn how to build a solution strategy in its early stages.

Korea needs improvement in the following systems: system for toxicity testing; system for cluster monitoring and epidemiologic studies; system for disease diagnosis and categorization; system for treatment; system for policy review.

In particular, the Ministry of Environment lacks an administrative structure that focuses on the health effects that hazardous substances cause, nor do they have a network that interactively engages in prevention, compensation, and policy-making across regions. All interested parties need to come together to understand the causes and effects from various angles with the a more general long-term perspective. 


\section{Conflict of Interest}

The authors have no conflicts of interest associated with the material presented in this paper.

\section{ORCID}

Sungkyoon Kim http://orcid.org/0000-0002-1378-8795

Domyung Paek http://orcid.org/0000-0003-4510-6362

\section{References}

1. Yang HJ, Kim HJ, Yu J, Lee E, Jung YH, Kim HY, et al. Inhalation toxicity of humidifier disinfectants as a risk factor of children's interstitial lung disease in Korea: a case-control study. PLoS One 2013;8(6):e64430.

2. Kim HJ, Lee MS, Hong SB, Huh JW, Do KH, Jang SJ, et al. A cluster of lung injury cases associated with home humidifier use: an epidemiological investigation. Thorax 2014;69(8):703-708.

3. Park JH, Kim HJ, Kwon GY, Gwack J, Park YJ, Youn SK, et al. Humidifier disinfectants are a cause of lung injury among adults in south korea: a community-based case-control study. PLoS One 2016;11(3):e0151849.

4. Paek D, Koh Y, Park DU, Cheong HK, Do KH, Lim CM, et al. Nationwide study of humidifier disinfectant lung injury in South Korea, 1994-2011. Incidence and dose-response relationships. Ann Am Thorac Soc 2015; 12(12):1813-1821.

5. Lee E, Seo JH, Kim HY, Yu J, Jhang WK, Park SJ, et al. Toxic inhalational injury-associated interstitial lung disease in children. J Korean Med Sci 2013;28(6):915-923.

6. Kim KW, Ahn K, Yang HJ, Lee S, Park JD, Kim WK, et al. Humidifier disinfectant-associated children's interstitial lung disease. Am J Respir Crit Care Med 2014;189(1):48-56.

7. Hong SB, Kim HJ, Huh JW, Do KH, Jang SJ, Song JS, et al. A cluster of lung injury associated with home humidifier use: clinical, radiological and pathological description of a new syndrome. Thorax 2014;69(8):694-702.

8. Yoon HM, Lee E, Lee JS, Do KH, Jung AY, Yoon CH, et al. Humidifier disinfectant-associated children's interstitial lung disease: computed tomographic features, histopathologic correlation and comparison between survivors and non-survivors. Eur Radiol 2016;26(1):235 243.

9. Kim YH, Kim KW, Lee KE, Lee MJ, Kim SK, Kim SH, et al. Transforming growth factor-beta 1 in humidifier disinfectant-associated children's interstitial lung disease. Pediatr Pulmonol 2016;51(2): 173-182.

10. Koo HJ, Do KH, Chae EJ, Kim HJ, Song JS, Jang SJ, et al. Humidifier disinfectant-associated lung injury in adults: prognostic factors in predicting short-term outcome. Eur Radiol 2017;27(1):203211.

11. National Institute of Environmental Research. Study on hazardous chemical substances in household chemical products and their health impact; 2014 [cited 2017 Jan 3]. Available from: http:// webbook.me.go.kr/DLi-File/NIER/06/021/5591231.pdf (Kore- an).

12. Park S, Lee K, Lee EJ, Lee SY, In KH, Kim HK, et al. Humidifier disinfectant-associated interstitial lung disease in an animal model induced by polyhexamethylene guanidine aerosol. Am J Respir Crit Care Med 2014;190(6):706-708.

13. Song JA, Park HJ, Yang MJ, Jung KJ, Yang HS, Song CW, et al. Polyhexamethyleneguanidine phosphate induces severe lung inflammation, fibrosis, and thymic atrophy. Food Chem Toxicol 2014;69:267-275.

14. Buxbaum A, Kratzer C, Graninger W, Georgopoulos A. Antimicrobial and toxicological profile of the new biocide Akacid plus. J Antimicrob Chemother 2006;58(1):193-197.

15. Scientific Committee on Consumer Safety, Bernauer U. Opinion of the scientific committee on consumer safety (SCCS)--2nd revision of the safety of the use of poly(hexamethylene) biguanide hydrochloride or polyaminopropyl biguanide (PHMB) in cosmetic products. Regul Toxicol Pharmacol 2015;73(3):885-886.

16. Assessment Report. 2-methylisothiazol-3(2H)-one (MIT): product-type 13 (metalworking-fluid preservative); 2014 [cited 2017 Jan 3]. Available from: http://dissemination.echa.europa.eu/Biocides/ActiveSubstances/1229-13/1229-13_Assessment_Report. pdf.

17. Scientific Committee on Consumer Safety. Opinion on: the mixture of 5-chloro-2-methylisothiazolin-3(2H)-one and 2-methylisothiazolin-3(2H)-one; 2009 [cited 2017 Jan 3]. Available from: http://ec.europa.eu/health//sites/health/files/scientific_committees/consumer_safety/docs/sccs_o_009.pdf.

18. Scientific Committee on Consumer Safety. Opinion of on the safety of poly(hexamethylene) biguanide hydrochloride (PHMB); 2014 [cited 2017 Jan 3]. Available from: http://ec.europa.eu/health// sites/health/files/scientific_committees/consumer_safety/docs/ sccs_o_157.pdf.

19. Burnett CL, Bergfeld WF, Belsito DV, Klaassen CD, Marks JG Jr, Shank RC, et al. Final report of the safety assessment of methylisothiazolinone. Int J Toxicol 2010;29(4 Suppl):187S-213S.

20. Jeon BH, Park YJ. Frequency of humidifier and humidifier disinfectant usage in Gyeonggi provine. Environ Health Toxicol 2012;27: e2012002.

21. Chang MH, Park H, Ha M, Kim Y, Hong YC, Ha EH. Characteristics of humidifier use in korean pregnant women: the mothers and children's environmental health (MOCEH) study. Environ Health Toxicol 2012;27:e2012003.

22. Asian Citizen's Center for Environment and Health. Population survey of humidifier disinfectant use; 2016 [cited 2017 Jan 3]. Available from: http://eco-health.org/bbs/board.php?bo_table=sub02 _04\&wr_id=160(Korean).

23. Lee JH, Kim YH, Kwon JH. Fatal misuse of humidifier disinfectants in Korea: importance of screening risk assessment and implications for management of chemicals in consumer products. Environ Sci Technol 2012;46(5):2498-2500.

24. Park D, Leem J, Lee K, Lim H, Choi Y, Ahn JJ, et al. Exposure characteristics of familial cases of lung injury associated with the use of humidifier disinfectants. Environ Health 2014;13:70.

25. Park DU, Friesen MC, Roh HS, Choi YY, Ahn JJ, Lim HK, et al. Estimating retrospective exposure of household humidifier disinfectants. Indoor Air 2015;25(6):631-640. 